\title{
Morpho-chemical divergence and fatty acid profile of shea tree seeds (Vitellaria paradoxa) collected from different locations in Kwara State, Nigeria
}

\author{
David Adedayo Animasaun ${ }^{1 *}$, Stephen Oyedeji ${ }^{1}$, Kehinde Stephen Olorunmaiye ${ }^{1}$, \\ Musibau A. Azeez ${ }^{2 *}$, Idowu Abdulfatah Tijani ${ }^{3}$, Joseph Akintade Morakinyo ${ }^{1}$ \\ ${ }^{1}$ Department of Plant Biology, Faculty of Life Sciences, University of Ilorin, Ilorin, Kwara State, Nigeria \\ ${ }^{2}$ Department of Pure and Applied Biology, Ladoke Akintola University of Technology, Ogbomoso, Oyo State, Nigeria \\ ${ }^{3}$ Department of Chemical Engineering, University of Ilorin, Ilorin, Kwara State, Nigeria
}

\begin{abstract}
The present study characterizes seed-related traits, phytochemical, physiochemical parameters and fatty acid profile of shea (Vitellaria paradoxa) seeds collected from the Kosubosu, Fufu and Sare areas of Kwara State, Nigeria to determine the effects of microclimate on seed morphology, biochemical and oil constituents. Seed morphological data were analyzed for variability. Seed oil was extracted for phytochemical constituents, physicochemical properties, and fatty acid profiling by gas chromatography equipped with mass spectrometry (GC/MS). Results showed intra and inter-locational variations in seed characters. Most fruits had 1-2 seeds. Seeds were predominantly brown and very few were dark brown. Phytochemicals and physicochemical parameters of the seed oil varied with place of collection. Alkaloid, saponin, tannin and phytate contents ranged between $0.79-0.84,1.20-1.26,1.48-1.56$ and $0.15-0.18 \mathrm{mg} \mathrm{g}^{-1}$ respectively. The density of the oil was less than that of water, acid value ranged from $10.58-13.56 \mathrm{mg} \mathrm{KOH} \mathrm{g}^{-1}$ and iodine values were between 36.63 to $40.32 \mathrm{~g} \mathrm{I}_{2}(100 \mathrm{~g})^{-1}$. Saponification values lie between 160.39 and $184.14 \mathrm{mg} \mathrm{KOH} \mathrm{g}^{-1}$; and free fatty acid was within 5.32-6.81\%. Peroxide, a-tocopherol, total phenol and oxalate values as well as viscosity of the oil also varied; however, refractive index was similar. Ethyl oleate and octadecanoic acids were present and most abundance in all the locations, while glycidol stearate was only found in Fufu samples with three other fatty acids. Five fatty acids were present in Kosubosu, while Sare had only two. The results obtained in the present study indicate that shea oil could be used for medicinal, nutritional and industrial purposes. Since seed characters, phytochemical, physicochemical and fatty acid compositions varied with the microclimate, environmental and micro-ecological conditions should be considered when collecting seeds for oil utilization.
\end{abstract}

Keywords: fatty acids, phytochemical analysis, physicochemical parameters, shea butter, Vitellaria paradoxa

\section{Introduction}

Vitellaria paradoxa Gaertn. F., commonly known as the shea tree is a tree of the Sapotaceae family indigenous to Sub-Sahara Africa where it grows in the wild and has huge economic and ecological potentials (Ademola et al. 2012). The tree occurs in West African and is popular among the local dwellers for its numerous social and economic utilizations (Kobomoje et al. 2013). The shea tree grows wild across a wide belt of savanna including West African countries of Senegal, Mali, Cote d' Ivoire, Burkina Faso, Togo, Ghana, Benin, Nigeria, Niger and Cameroon. The tree is also found further to the east, in Uganda, Sudan and Ethiopia (Maranz et al. 2004, Goreja 2004, Masters et al. 2010). Among these countries, Ghana and Burkina Faso are the main Shea net exporters (Walter et al. 2003). In Nigeria, the shea tree is known as "Emi" among the Yoruba people of the western part. The shea grows up to 9-12 $\mathrm{m}$ in height with profuse branches. Commercial fruiting quantity usually commences at approximately 20 years and the tree can continuously produce shea fruit for many more years (Alander 2004). Late maturity of the tree has been the bane of its commercial plantation and shea butter related industries depend on nuts collected from scattered, naturally growing shea trees. In Nigeria, the

*Corresponding authors: animasaun.ad@unilorin.edu.ng, musibau_azeez@yahoo.com 
shea is found in the Guinea savanna with high tree concentrations in Niger, Kwara, Kebbi and Kaduna states (Warra 2011). Shea trees blossom between February to March, and the fruit matures and falls in May-June. The fruit is ellipitic, yellow green or light green, about 5-8 $\mathrm{cm}$ in circumference and similar to the fig (Chalfin 2004). The fruit has a butterlike, mucous pericarp covering an oval brown or light brown seed surrounded by a fragile shining shell with a large hilum on a broad base (Olaniyan et al. 2007). Usually, a shea fruit contains one seed but occasionally has two to three oil-rich nuts (Alander 2004).

The shea tree has the potential to improve nutrition, boost healthcare, reduce rural poverty and support sustainable land care (Moore, 2008). The fruit pulpy pericarp can be eaten while the nut is discarded or crushed for shea butter extraction. The fat obtained from the shea nut known as shea butter (Ori: Yoruba; Nigeria), which contains $40-60 \%$ oil, is the most valued product from the shea tree (Warra and Komo, 2014). Shea butter is used for local domestic purposes such as cooking, lightning, soap making, skin moisturizer and cosmetics as well as traditional medicine among the local population where the tree grows in abundance in Nigeria. Also, it is used to treat wounds, suppress inflammation, relieve rheumatic and joint pains and other health conditions (Kraft and Lynde 2005, Soro et al. 2011, Warra and Komo 2014). The potential of shea oil to protect the skin from damaging ultra violet rays was demonstrated by Velasco et al. (2008). On a global scale, the importance of the shea tree is related to the usefulness of its seed fat in food and cosmetic industries. Decolourised shea butter could be used as a cheaper alternative to cocoa butter due to their similar physical and chemical properties (Lipp et al. 2001, Alander 2004). The high levels of unsaponifiable matter in shea nut oil compared to other vegetable fats could be exploited for the development of more shea butter products (Rogers and Lenick 2009). Shea oil finds applications in traditional and social rituals such as marriages, funerals, coronations and rainmaking (Ferris et al. 2004, Gwali et al. 2011, Hall et al. 1996, Moore 2008). Also, high grade charcoal and furniture are made from the wood while the latex yields a considerable amount of glue (Lovett and Haq 2000). Consequently, the shea tree could generate significant incomes for the rural households.

However, despite the enormous economic and healthcare potentials, shea butter and its products are underutilised in Nigeria and only little information is available on the seed variability. In particular, not much work has been done on locational variation of seed characters in relation to the nut phytochemicals and fatty acid characterization of seeds from different locations. The present work was carried out to characterize seed related traits, quantify phytochemical constituents of the nut and profile the fatty acids of the shea seed collected from different locations in Kwara State, Nigeria. This study hopes to identify existing variations in the shea seeds from different locations using seed and oil characteristics to throw more light on how microclimate affects seed morphology and chemical constituents in shea tree.

\section{Materials and methods}

\section{Fruit and seed collection}

Vitellaria paradoxa fruits were collected from three locations in Kwara State, Nigeria, because of the abundance of shea trees, the folkloric processing and utilization of shea butter for socio-economic purposes. Kwara State is located in the Southern Guinea savanna belt of Nigeria, which is dominated by grasses interspersed mainly with tree species such as Daniellia oliveri, Vitellaria paradoxa, Prosopis africana and Parkia biglobosa. The state is within the coordinates $8^{\circ} 30^{\prime} 0.00^{\prime \prime} \mathrm{N}$ and $4^{\circ} 32^{\prime} 32^{\prime \prime} \mathrm{E}$ and at an elevation of $303 \mathrm{~m}$ above sea level (NGIA, 2016). The names and coordinates of the three locations from where shea fruits and seeds are collected are shown in Table 1. The soil was mainly sandy, lateritic or ferralitic, mean annual rainfall is $640-1350 \mathrm{~mm}$. Usually, the rainy season lasts from May to October and dry season from November to April. Relative humidity is $75-80 \%$ in the wet season and about $65 \%$ during the dry season (Ajadi et al. 2011). The average monthly temperature is $31.4-33.5^{\circ} \mathrm{C}$, but fluctuates between 33 and $34^{\circ} \mathrm{C}$ from November to January and $34-35^{\circ} \mathrm{C}$ (February to April) (Ilorin Atlas, 1982; NIMET, 2016).

Tab. 1. Names, local division, coordinates and elevations of the locations from where shea fruits and seeds were collected for the study in Kwara State of Nigeria.

\begin{tabular}{cccc}
\hline $\begin{array}{c}\text { Location } \\
\text { name }\end{array}$ & $\begin{array}{c}\text { Local government } \\
\text { area }\end{array}$ & Coordinates & Altitude $(\mathrm{m})$ \\
\hline Kosubosu & Baruten & $9^{\circ} 35^{\prime} \mathrm{N}, 3^{\circ} 15^{\prime} \mathrm{E}$ & $273-364$ \\
Fufu & Ilorin West & $8^{\circ} 30^{\prime} \mathrm{N}, 4^{\circ} 32^{\prime} \mathrm{E}$ & $300-310$ \\
Sare & Ifelodun & $9^{\circ} 40^{\prime} \mathrm{N}, 3^{\circ} 22^{\prime} \mathrm{E}$ & $370-418$ \\
\hline
\end{tabular}

\section{Fruit and seed morphological studies}

Ten mature fruit bearing trees were selected at each location (Kosubosu, Fufu and Sare) from May to July, 2016. Each location has five sites from which two fruiting trees were selected. Thirty ripe fruits were randomly plucked from each tree for characterization. Epicarp thickness and seed diameter were determined using an electronic vernier calliper (ATD-8656). Number of seed per fruit, seed dimension and seed coat colour were also recorded; the mean values of ten readings were used for the seed characters.

\section{Shea nuts oil extraction}

The pulpy pericarp of the fruits were removed, the seeds cleaned and sun dried for two weeks. The dried seeds were deshelled, the kernels were ground and kept in airtight containers prior to oil extraction. Oil extraction was carried out in Soxhlet apparatus using n-hexane as solvent. $50 \mathrm{~g}$ of the ground material was transferred to a $30 \mathrm{~mm} \times 200 \mathrm{~mm}$ cellulose thimble placed in the extraction chamber of a $250 \mathrm{~mL}$ Soxhlet apparatus fitted with a condenser on a $500-\mathrm{mL}$ distillation flask containing $250 \mathrm{~mL}$ of $\mathrm{n}$-hexane solvent. Shea nut oil was extracted under reflux with n-hexane following 
the procedure described by Ali et al. (2015). After extraction, hexane was removed by using a heated rotary evaporator (Stuart, England), under vacuum conditions to recover the oil. Extractions of oil from seeds of different locations were performed in triplicate, and the mean values were reported. Oil yield was expressed as percentage weight of oil obtained relative to the weight of shea butter used for extraction according to Warra et al. (2011).

\section{Phytochemical and physicochemical properties determination}

Methanolic extracts of the shea nut were screened for presence or otherwise of bioactive compounds using standard procedures (Sofowora 1993, Kokate 1999, Kumaran and Karunakaran 2006). The amount of tannin was estimated using the method described by Hagerman et al. (2000), saponin, and alkaloid present in the shea nut extract were determined according to procedure of Obadoni and Ochuko (2001). Total phenol, oxalate and phytate contents in the extract were quantified according to the methods of Yadav et al. (2011) and Falana et al. (2016), while the amount of a-tocopherol was determined by the standard procedure of he Association of Official Analytical Chemists (2010).

Iodine values (IV) of the shea oil were estimated using the method of Gafar et al. (2012). The value was calculated from fatty acid methyl ester compositions of oil. Saponification value was calculated from fatty acid methyl ester compositions of oil using the equation of Kalayasiri et al. (1996). Determination of the acid value, which is the amount of carboxylic acid groups in the oil, was carried out based on a titration method using the AOAC (2010) procedure. Viscosity of the shea butter oil was recorded using an Ostwald viscometer (DV-III ultra, UK). The free fatty acid of the oil was estimated by placing $0.2 \mathrm{~g}$ of oil into $250 \mathrm{~cm}^{3}$ Erlenmeyer flask, $100 \mathrm{~cm}^{3}$ of ethanol was added and followed by $2 \mathrm{~cm}^{3}$ of phenolphthalein indicator. The mixture was titrated against $0.1 \mathrm{M} \mathrm{NaOH}$ till endpoint (slight pink colour that persists for 30seconds), the free fatty acid was calculated according to Chopra and Kanwar (1991). To determine the peroxide value of the oil, $2.0 \mathrm{~g}$ of oil was added to $22 \mathrm{~cm}^{3}$ of a solution containing $12 \mathrm{~cm}^{3}$ chloroform and $10 \mathrm{~cm}^{3}$ acetic acid. 0.5 $\mathrm{cm}^{3}$ saturated potassium iodide was added and allowed to stay with intermittent agitation for 1 minute before $30 \mathrm{~cm}^{3}$ distilled water was added. The mixture was titrated against $0.1 \mathrm{M}$ of $\mathrm{Na}_{2} \mathrm{~S}_{2} \mathrm{O}_{3}$ in the presence of starch indicator until the blue colour had just disappeared. The peroxide value determination was carried out in accordance with Neilson (2003). Refractive index of the oil with reference to air was measured with the Abbe Refractometer (Mettler-Toledo, USA). The specific gravity of the oil relative to water was measured by hydrometer.

\section{Fatty acid profiling}

Fatty acid composition of the oil was determined at the Chemical Engineering Laboratory, University of Ilorin, $\mathrm{Ni}$ geria by a gas chromatograph equipped with a mass spec- trometer (GC/MS; Agilent Technologies; Model: 7890A) with $\mathrm{HP}$ column, $30 \mathrm{~cm}$ long $\times 0.32 \mathrm{~mm}$ ID $\times 0.25 \mu \mathrm{m}$ thickness film (SGE, Australia). The GC is fitted with Hewlett Packard (USA) flame ionization detector (FID) and 99.9\% helium was used as carrier gas. The oil triacylglycerides (TG) was converted to fatty acid methyl ester (FAME) to decrease the boiling point. $0.2 \mathrm{~mL}$ of biodiesel was added to a $1 \mathrm{~mL}$ mixture consisting of hexane and 2-propanol (4/5 volume ratio). Before charging the oil, the samples were purified by filtration using $0.2 \mu \mathrm{m}$ polytetrafluoroethylene syringe micro filter, then $1 \mu \mathrm{L}$ of the sample was injected into the GC/MS using a $5 \mu \mathrm{L}$ micro syringe (SGE, Australia). The gas chromatography condition was continuous flow mode. The inlet temperature was $250^{\circ} \mathrm{C}$ while the oven temperature was $250^{\circ} \mathrm{C}$. The injection volume was $1 \mu \mathrm{L}$ and the split ratio 1:50. The procedure was run for 20 minutes with an average velocity of $37.789 \mathrm{~cm} \mathrm{~s}^{-1}$ at 17.04 psi pressure. On the other hand, the mass spectrometry was run under transfer line temperature of $240^{\circ} \mathrm{C}$, source temperature at $220^{\circ} \mathrm{C}$. The solvent delay was for 2 minutes while the scan mass range was $45-500$. Data analysis was conducted with GC/MSD ChemStation Integrator software.

\section{Results}

The fruits and seeds of the shea tree collected from three selected local government areas of Kwara State, Nigeria varied in number of seed/fruit, pericarp thickness, seed coat colour and seed dimension as well as phytochemical and fatty acid constituents. Among the 300 shea fruits (30/tree) collected from Kosubosu, Baruten Local Government Area, 265 (88.33\%) had 1 seed/fruit, 34 were 2 -seeded and only one fruit had 3 seeds (Tab. 2). The average ratios of seeds to fruit were 26.5, 3.4 and 0.1 for 1-seed, 2-seed and 3-seed fruits respectively. In addition, 164 of the seeds had brown seed coats, 112 were light brown while 24 were dark brown. The fruits collected from Fufu (Ilorin West Local Govt Area) are predominantly one seeded. $254(84.66 \%)$ of the fruits were 1 -seed, 42 had 2 seeds per fruit and 4 fruits were found with 3 seeds each (Tab. 2). The seed colour distribution showed 129 light brown seeds, 121 brown and 50 dark brown seed coats. Similarly, 1-seed fruits occurred most among the fruits collected from Sare (Ifelodun Local Govt Area). 252 out of the 300 sampled fruits had 1 seed, 2 seeds per fruit were found in 44 and 3 seeds occurred in 5 fruits. Brown seeds were the most frequent (160) followed by light brown (119) and the few (21) dark brown seeds were from Sare samples.

The mean epicarp thickness ranged from $2.77-3.48 \mathrm{~mm}$ in fruits collected from Kosubosu (Fig. 1a). Mean seed diameter and circumference ranged between 2.41 to $3.95 \mathrm{~cm}$ and 6.44 to $7.46 \mathrm{~cm}$, respectively. Similarly, seed lengths among the Kosubosu seed population were alike. Considering fruit and seed characters, Fufu fruits had mean pericarp thickness between $2.88-3.36 \mathrm{~mm}$ (Fig. 1b). The seed diameter and circumference were smaller than those of Kosubosu and ranged between 2.41 and $87 \mathrm{~cm}$ and 5.66 and $7.10 \mathrm{~cm}$ respectively. The greatest seed length was $4.96 \mathrm{~cm}$ while the least was $3.88 \mathrm{~cm}$. Seed diam- 

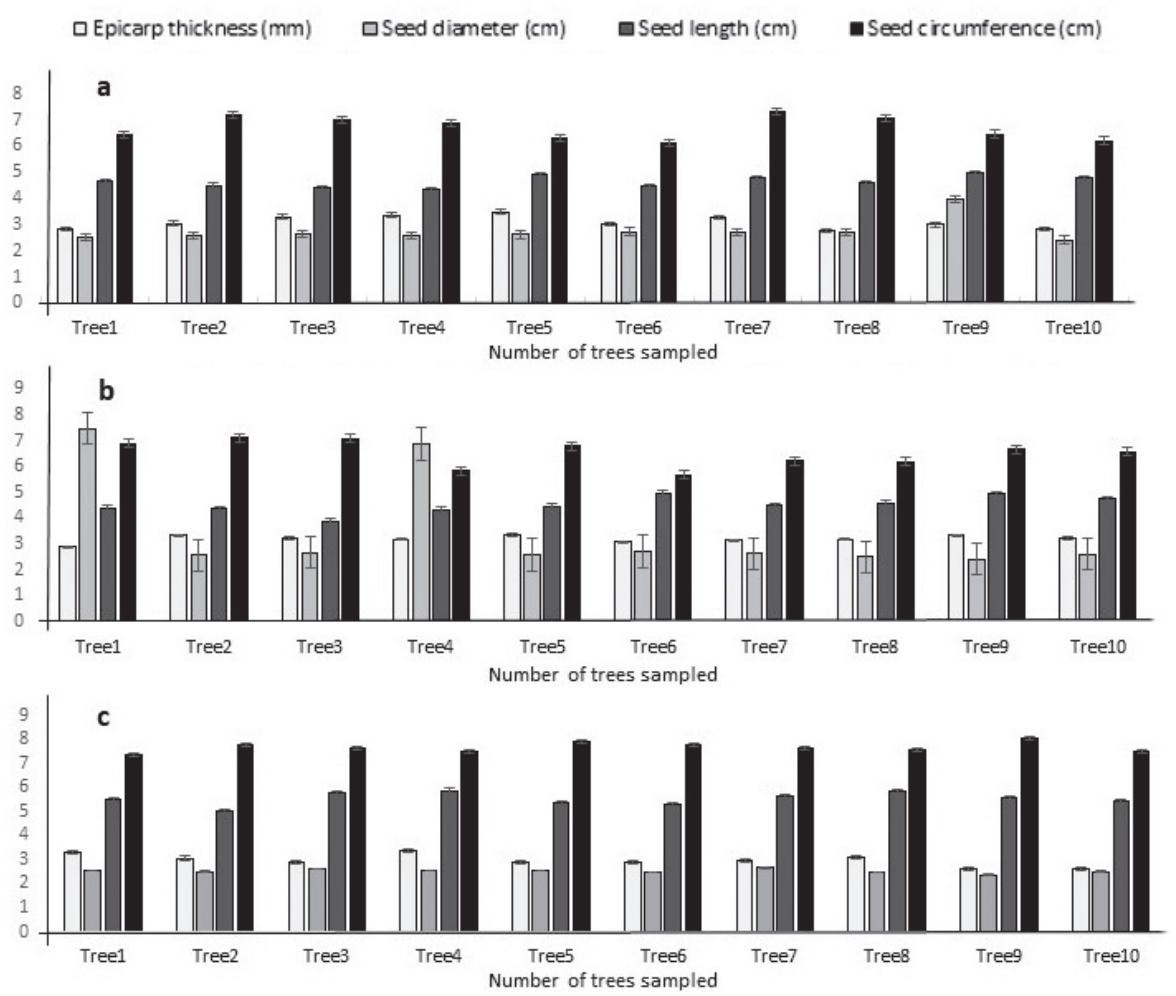

Fig. 1. Morphological seed related characters of shea tree seeds collected from different locations in Kwara State, Nigeria: (a) Kosubosu, Baruten, (b) Fufu, Ilorin West, (c) Sare, Ifelodun.

Tab. 2. Morphological characteristics of shea tree seeds collected from selected locations in three local government areas of Kwara State, Nigeria. TN - number of tree, NFS - number of seeds collected, DB- dark brown, LB- light brown, B - brown.

\begin{tabular}{|c|c|c|c|c|c|c|c|c|c|c|c|c|c|c|c|c|c|c|c|}
\hline \multirow{3}{*}{$\mathrm{TN}$} & \multirow{3}{*}{ NFS } & \multicolumn{6}{|c|}{ Kosubosu } & \multicolumn{6}{|c|}{ Fufu } & \multicolumn{6}{|c|}{ Sare } \\
\hline & & \multicolumn{3}{|c|}{ No of seed/fruit } & \multicolumn{3}{|c|}{ Seed colour } & \multicolumn{3}{|c|}{ No of seed/fruit } & \multicolumn{3}{|c|}{ Seed colour } & \multicolumn{3}{|c|}{ No of seed/fruit } & \multicolumn{3}{|c|}{ Seed colour } \\
\hline & & 1 & 2 & 3 & $\mathrm{DB}$ & LB & B & 1 & 2 & 3 & $\mathrm{DB}$ & $\mathrm{LB}$ & B & 1 & 2 & 3 & DB & $\mathrm{LB}$ & $\mathrm{B}$ \\
\hline 1 & 30 & 29 & 1 & 0 & & 13 & 17 & 22 & 7 & 1 & 6 & 13 & 11 & 13 & 16 & 2 & 1 & 13 & 16 \\
\hline 2 & 30 & 24 & 6 & 0 & 7 & 11 & 12 & 26 & 3 & 1 & 0 & 22 & 8 & 29 & 1 & 0 & 3 & 10 & 17 \\
\hline 3 & 30 & 30 & 0 & 0 & 3 & 3 & 24 & 28 & 2 & 0 & 0 & 14 & 16 & 28 & 2 & 0 & 3 & 7 & 20 \\
\hline 4 & 30 & 30 & 0 & 0 & 4 & 9 & 17 & 30 & 0 & 0 & 25 & 4 & 1 & 29 & 0 & 1 & 4 & 9 & 17 \\
\hline 5 & 30 & 30 & 0 & 0 & 0 & 15 & 15 & 23 & 7 & 0 & 3 & 10 & 17 & 25 & 5 & 0 & 0 & 14 & 16 \\
\hline 6 & 30 & 14 & 15 & 1 & 10 & 5 & 15 & 26 & 4 & 0 & 1 & 4 & 25 & 28 & 2 & 0 & 3 & 8 & 19 \\
\hline 7 & 30 & 29 & 1 & 0 & 0 & 21 & 9 & 28 & 2 & 0 & 0 & 19 & 11 & 21 & 8 & 1 & 1 & 21 & 8 \\
\hline 8 & 30 & 28 & 2 & 0 & 0 & 19 & 11 & 24 & 5 & 1 & 4 & 18 & 8 & 26 & 3 & 1 & 2 & 18 & 10 \\
\hline 9 & 30 & 22 & 8 & 0 & 0 & 3 & 27 & 28 & 2 & 0 & 7 & 14 & 9 & 23 & 7 & 0 & 0 & 8 & 22 \\
\hline 10 & 30 & 29 & 1 & 0 & 0 & 13 & 17 & 19 & 10 & 1 & 4 & 11 & 15 & 30 & 0 & 0 & 4 & 11 & 15 \\
\hline$\Sigma$ & 300 & 265 & 34 & 1 & 24 & 112 & 164 & 254 & 42 & 4 & 50 & 129 & 121 & 252 & 44 & 5 & 21 & 119 & 160 \\
\hline mean & 30 & 26.5 & 3.4 & 0.1 & 2.4 & 11.2 & 16.4 & 25.4 & 4.2 & 0.4 & 5.0 & 12.9 & 12.1 & 25.2 & 4.4 & 0.5 & 2.1 & 11.9 & 16.0 \\
\hline
\end{tabular}

eter and circumference were similar for the fruits collected from 10 different trees in Sare, but pericarp thickness and seed length varied (Fig. 1c). The fruits and seeds are smaller than those of Kosubosu and Fufu areas. The average pericarp thickness, seed diameter and length were between 2.61 and $3.37 \mathrm{~mm}, 2.47$ and $2.66 \mathrm{~cm}, 5.02$ and $5.82 \mathrm{~cm}$ respectively, however, seed circumference varied from $7.02-7.70 \mathrm{~cm}$.

The phytochemical compositions of the shea nut are presented in Table 3. Highest phytate, tannin, total phe- nol and alkaloids were found in nuts from Kosubosu which invariably had the least amount of a-tocopherol. The order of the amount of a-tocopherol in the samples was Sare $>$ Fufu $>$ Kosubosu while saponin content was highest $\left(1.26 \mathrm{mg} \mathrm{g}^{-1}\right)$ in samples from Sare, followed by Kosubo$\mathrm{su}\left(1.21 \mathrm{mg} \mathrm{g}^{-1}\right)$ and the least $\left(1.20 \mathrm{mg} \mathrm{g}^{-1}\right)$ in Fufu. In contrast, Fufu samples produced the highest amount of oxalate $\left(0.82 \mathrm{mg} \mathrm{g}^{-1}\right)$ as against $0.80 \mathrm{mg} \mathrm{g}^{-1}$ from Kosubosu and $0.78 \mathrm{mg} \mathrm{g}^{-1}$ obtained from Sare samples. 
Tab. 3. Phytochemical composition of shea butter from different locations in Kwara State, Nigeria.

\begin{tabular}{lccc}
\hline \multirow{2}{*}{ Phytochemical constituent } & \multicolumn{3}{c}{ Location } \\
\cline { 2 - 4 } & Kosubosu & Fufu & Sare \\
\hline Phytate $\left(\mathrm{mg} \mathrm{g}^{-1}\right)$ & 0.18 & 0.15 & 0.16 \\
Tannins $\left(\mathrm{mg} \mathrm{g}^{-1}\right)$ & 1.56 & 1.50 & 1.48 \\
Oxalate $\left(\mathrm{mg} \mathrm{g}^{-1}\right)$ & 0.80 & 0.82 & 0.78 \\
Total phenol $\left(\mathrm{mg} \mathrm{g}^{-1}\right)$ & 0.52 & 0.50 & 0.49 \\
a-Tocopherol $\left(\mathrm{mg} \mathrm{g}^{-1}\right)$ & 26.38 & 28.60 & 34.42 \\
Alkaloid $\left(\mathrm{mg} \mathrm{g}^{-1}\right)$ & 0.84 & 0.79 & 0.80 \\
Saponin $\left(\mathrm{mg} \mathrm{g}^{-1}\right)$ & 1.21 & 1.20 & 1.26 \\
\hline
\end{tabular}

Percentage oil yield of the shea nut was highest (53.06\%) for Kosubosu, followed by Sare (49.26\%) and the least in Fufu (47.31\%) (Tab. 4). The specific gravity and refractive index of the oil from the different locations were similar, but the least acid value, iodine value and free fatty acid were recorded for Kosubosu samples. Saponification value was higher (184.14 $\left.\mathrm{mg} \mathrm{KOH} \mathrm{g}^{-1}\right)$ in the Sare sample than in the Kosubosu (182.15 $\mathrm{mg} \mathrm{KOH} \mathrm{g}^{-1}$ ) but a much lower value was obtained for Fufu (160.39 $\left.\mathrm{mg} \mathrm{KOH} \mathrm{g}^{-1}\right)$ which invariably had the highest viscosity. Furthermore, the order of peroxide values in the shea oil was Kosubosu $>$ Sare $>$ Fufu (Tab. 4).
Table 5 shows the retention time, types and percentage composition of the fatty acids present in shea nut oils. Five fatty acids were found in Kosubosu samples, four in Fufu and only two in Sare. 2-hydroxyl-1(hydroxymethyl) ethyl ester with percentage compositions of 38.89 and $47.43 \%$ was the most abundant fatty acid in Kosubosu and Fufu samples respectively; it was however not found in Sare samples. Ethyl oleate constituted $59.96 \%$ of the total fatty acids in the Sare sample and octadecanoic acid accounted for $40.04 \%$. While ethyl oleate and octadecanoic acids were common to all the locations, hexadecanoic acid was present in a trace amount (1.36\%) only in Kosubosu.

\section{Discussion}

Analysis of seed/fruit revealed that fruits from different locations are predominantly one-seeded, a few had 2 seeds per fruit, and 3 seeds per fruit are rare. Although, shea fruit is a berry, occurrence of more than two seeds in a fruit is a rare phenomenon. The higher frequency of one-seeded fruit in Kosubosu than in other locations may be due to environmental and/or edaphic variations. This observation aligned with the seed number variation among fruits from the same tree as reported by Abbiw (1990) and Djekota et al. (2014) who claimed that $2-3$ seeds were found in some shea

Tab. 4. Oil yield and physicochemical parameters of extracted shea butter oil from different locations of Kwara State, Nigeria.

\begin{tabular}{|c|c|c|c|}
\hline \multirow{2}{*}{ Physicochemical property } & \multicolumn{3}{|c|}{ Location } \\
\hline & Kosubosu & Fufu & Sare \\
\hline Oil yield (\%) & $54.60 \pm 2.71$ & $46.35 \pm 2.18$ & $49.25 \pm 2.63$ \\
\hline Specific Gravity $\left(\mathrm{g} \mathrm{cm}^{-3}\right)$ & $0.90 \pm 0.01$ & $0.90 \pm 0.01$ & $0.90 \pm 0.01$ \\
\hline Acid value (mg KOH g $\left.{ }^{-1}\right)$ & $10.58 \pm 0.70$ & $13.56 \pm 0.94$ & $13.16 \pm 0.91$ \\
\hline Iodine value $\left(\mathrm{g} \mathrm{I}_{2}(100 \mathrm{~g})^{-1}\right)$ & $36.63 \pm 2.67$ & $40.32 \pm 3.52$ & $39.28 \pm 2.91$ \\
\hline Free fatty acid (\% oleic acid) & $5.32 \pm 0.49$ & $6.81 \pm 0.53$ & $6.60 \pm 0.56$ \\
\hline Reflective index & $1.46 \pm 0.09$ & $1.46 \pm 0.09$ & $1.46 \pm 0.09$ \\
\hline Saponification value (mg KOH g-1) & $182.15 \pm 3.18$ & $160.39 \pm 2.90$ & $184.14 \pm 3.14$ \\
\hline Peroxide value $\left(\mathrm{mEq} \mathrm{kg}{ }^{-1}\right)$ & $5.20 \pm 0.07$ & $4.10 \pm 0.08$ & $4.82 \pm 0.04$ \\
\hline Viscosity & $2.60 \pm 0.02$ & $2.70 \pm 0.01$ & $2.61 \pm 0.02$ \\
\hline
\end{tabular}

Tab. 5. Chemical composition of the extracted shea nut oil from different locations in Kwara State, Nigeria.

\begin{tabular}{llcc}
\hline Location & Compound name & Retention time (min) & \% composition \\
\hline \multirow{4}{*}{ Kosubosu } & Hexadecanoic acid, ethyl ester & 33.175 & 1.36 \\
& Ethyl oleate & 36.267 & 20.89 \\
& Octadecanoic acid, ethyl ester & 36.768 & 15.78 \\
& 2-hydroxyl-1(hydroxymethyl) ethyl ester & 41.262 & 38.80 \\
& 2-hydroxyl-1,3-propanediyl ester & 41.685 & 23.18 \\
\hline \multirow{3}{*}{ Fufu } & Ethyl oleate & 36.267 & 7.21 \\
& Octadecanoic acid ethyl ester & 36.768 & 4.25 \\
& 2-hydroxyl-1(hydroxymethyl) ethyl ester & 44.306 & 47.43 \\
Sare & Glycidol stearate & 41.729 & 41.13 \\
\hline
\end{tabular}


fruits collected from different locations of Mondoul in the Chad Republic. Fruit and seed morphological parameters such as pericarp thickness, petiole length, seed dimensions were used to partition populations of shea tree (Djekota et al. 2014). Seed coat colours were mainly in three categories (dark brown, light brown and brown), but while light brown and brown seeds occurred frequently, only very few seeds had dark brown coat for fruits obtained from same tree in a location. Variation in seed colour observed in the present study matched previous findings on shea nut seed coat (Nafan et al. 2007, Lamien et al. 2007). Since seed formation involves meiosis, coat colouration in this case is most likely genetic and can be caused by mutation or recombination of genes. Also, these variations can be explained by natural and/ or human selection and gene flow mediated from genetic drift (Tremblay et al. 2010, Abasse et al. 2011). Differences recorded in quantitative seed characters intra and inter-locational in the present study concurred with the findings on Tamarindus indica (Soloviev et al. 2004). Furthermore, significant intra and inter-locality variations have been demonstrated in shea tree and seed characters (Mbaiguinam et al. 2007, Gwali et al. 2011).

The phytochemical constituents varied with locations, the variations could be accounted for by environmental stress, rainfall regimes and soil characteristics as opined by Sanou et al. (2005). Amount of phytochemicals were less than those obtained by Falana et al. (2016) who worked on $V$. paradoxa collected from Onipako village, Ilorin and this could be due to locational differences. The presence of similar phytochemicals has been reported in other tropical plants in Nigeria and some of them exhibit varying biological activities (Sofowora 1993, Onwuliri 2004).

The oil yield varied with locations, and the higher amount of oil obtained from the Kosubosu seeds could be explained by the same factors that account for the morphological and biochemical compositions. The yield of the oil from the study locations were in accordance to the values earlier reported (Warra and Komo 2014). The present study revealed that in terms of oil yield, Kosubosu samples are the best. Physicochemical parameters are of great importance in determination of oil quality. Pure oils have marked ranges of specific gravity and refractive index; thus the degree of variation of typical oil from its true values may indicate its relative purity. The specific gravity of the extracted shea nut oil was less than $1.0 \mathrm{~g} \mathrm{~cm}^{-3}$, which implies the oil is less dense than water. The specific gravity of $0.902 \mathrm{~g} \mathrm{~cm}^{-3}$ obtained in this study correlates with the $0.90 \mathrm{~g} \mathrm{~cm}^{-3}$ documented by Raimi et al. (2014) and is congruent with those of Persea macrophylla $\left(0.89 \mathrm{~g} \mathrm{~cm}^{-3}\right)$ and Persea gratesima $\left(0.90 \mathrm{~g} \mathrm{~cm}^{-3}\right)$ (Akubugwo et al. 2008). Furthermore, the refractive index (1.468), which was the same for the locations, was also the same as the value reported by Raimi et al. (2014) and similar to Anacandium occidentlis oil (1.458) (Akinhanmi et al. 2008) and walnut kernel oil (1.534) (Ozcan et al. 2010). The iodine value of the oil suggests it is a typical nondrying oil containing saturated and a low level of unsaturated fatty acid. Hence, the oil may be utilized for vegetable oil-based ice cream manufacturing, but, the non-drying nature of the oil makes it not applicable for paint and varnish production. Shea oil from Fufu has low saponification value compared with the other two locations. The range of saponification indicates that the oil may be useful in making soap and shampoo (Ugbogu et al. 2013). Low acid value of the shea nut oil although higher than value reported by Raimi et al. (2014) was far less than of Livistona. chinensis (Nwosu et al. 2012) and this signify it could be used as an edible oil. The free fatty acid which is also an indicator of oil edibility was low and close to the range reported by Ugbogu et al. (2013). This suggests a low level of hydrolytic and lipolytic activities in the oil, thus, the extracted oil could be used as raw materials for industries (Obasi et al. 2012).

Analysis of the fatty acid profile of shea nut oil revealed the presence of 6 fatty acids in varying quantities. It is of interest to note that while five fatty acids were found in Kosubosu samples, four were present in Fufu and only two in Sare samples. Ethyl oleate and octadecanoic acids were present in all the samples irrespective of their locations. This result buttresses an earlier report that variation exists in fatty acid composition of same seed oil from different locations (Wara, 2015). Ethyl oleate acid which is the most abundant in the extracted shea nut oil is an unsaturated fatty acid, naturally present in most seed oil and can be used for lotion and pharmaceutical solvents (PubChem, 2014). The variation in chemical constituents and fatty acid composition of the studied samples may be accounted for by environmental variations (Sanou et al. 2005, Mbaiguinam et al. 2007). This explains why 2-hydroxyl,3-propanediyl ester, was only present in Kosubosu samples while glycidol stearate occurred only in Fufu samples. Hexadecanoic acid ethylester (palmitic acid), used mainly for soaps, cosmetics and release agent production, was present only in Kosubosu shea nut oil. Thus, considering the fatty acid composition of the shea nut oil, its industrial and domestic application potentials, locational variation should be taken into consideration in collecting seeds for oil production. The present study revealed that shea tree seeds from Kosubosu had a higher yield in term of quantity and quality of shea nut oil than the other two locations.

\section{Conclusion}

The present study showed that morphological variations exist within and among locations in the seed characters of $V$. paradoxa from different areas of Kwara State in Central Nigeria. Also, from the results, shea nut oil phytochemical constituents and physicochemical parameters varied with locations of seed collection. The fatty acid also varied with locations and the presence of vital fatty acids in a large percentage in the oil enhances the potential of shea oil as a candidate oil for industrial revolution and rural economy development. However, in sourcing for shea seed for butter and oil production, locational variations should be taken into consideration as important factors that could affect oil quantity and quality. The present study can be extended to other regions where the 
trees are endemic and the molecular approach could be used for a better understanding of the existing variability among the shea tree and nut populations.

\section{References}

Abasse, T., Weber, J., Katkore, B., Boureima, M., Larwanou, M., Kalinganire, A., 2011: Morphological variation in Balanites aegyptiaca fruits and seeds within and among parkland agroforests in eastern Niger. Agroforestry System 81, 57-66.

Abbiw, D. K., 1990: Useful plants of Ghana: West African uses of wild and cultivated plants. Intermediate Technology Publications, London.

Ademola, A. O., Osewa, S. O., Oyesola, O. B., 2012: Assessment of shea butter processing among rural dwellers in Atisbo Local Government Area of Oyo State, Nigeria. European Journal of Business and Social Sciences 1, 01-08.

Ajadi, B. S., Adeniyi, A., Afolabi, A. M., 2011: Impact of climate on urban agriculture: case study of Ilorin city, Nigeria. Global Journal of Human Social Sciences 11, 26-29.

Alander, J., 2004: Shea butter - A multifunctional ingredient for food and cosmetics. Lipid Technology 16, 202-205.

Ali, M. A., Tahseen, A., Imad, T. A., Al-Hydary, A., 2015: Extraction of date palm seed oil (Phoenix dactylifera) by Soxhlet apparatus. International Journal of Advances in Engineering and Technology 8, 261-271.

Akinhanmi, T. F., Atasu, V. N., Akintokun, P. O., 2008: Chemical composition and physicochemical properties of cashew nut (Anacardium occidentale) oil and cashew nut shell liquid. Journal of Agriculture, Food and Environmental Sciences 2, $1-10$.

Akubugwo, J. E., Chinyere, G. C., Ugbogu, A. E. 2008: Comparative studies on oils from some common plant seeds in Nigeria. Pakistan Journal of Nutrition 7, 570-573.

AOAC., 2010: Official methods of analysis. Association of Official Analytical Chemists, 15th Edition, Washington D.C., USA.

Chalfin, B., 2004: Shea butter republic. Routledge, New York, N.Y. Intro, $\mathrm{CHI}$.

Chopra, S. L., Kanwar, J. S., 1991: Analytical agricultural chemistry, 4th Edition, Kalyami Publishers, New Delhi.

Djekota, C., Diouf, D., Sane, S., Mbaye, S. S., Noba, K., 2014: Morphological characterization of shea tree (Vitellaria paradoxa subsp. paradoxa) populations in the region of Mandoul in Chad. International Journal of Biodiversity and Conservation 6, 184-193.

Falana, M. B., Bankole, M. O., Ojo, D. A., Omemu, A. M., 2016: Comparative phytochemical investigation of the various parts of Vitellaria Paradoxa. Journal of Natural Sciences Research $6,74-80$

Ferris R.S.B., Collinson, C., Wanda, K., Jagwe, J., Wright, P., 2004: Evaluating the market opportunities for shea nut and Shea nut processed products in Uganda. Technical Report. Natural Resources Institute, Chatham, UK. Retrived from http://gala.gre. ac.uk/id/eprint/11972.

Gafar, M. K., Itodo, A. U., Warra, A. A., Abdullahi, L., 2012: Extraction and physicochemical determination of garlic (Allium sativum $L$ ) oil. International Journal of Food and Nutrition Science 1, 4-7.

Goreja, W.G., 2004: Shea butter: The nourishing properties of Africa's best kept natural beauty. Amazing Herbs Press. New York, NY.

Gwali, S., Okullo, J. B. L., Eilu, G., Nakabonge, G., Nyeko, P., Vuzi, P., 2011: Folk classification of Shea butter tree (Vitellaria para-

\section{Acknowledgment}

The efforts of technologists, Department of Chemical Engineering, University of Ilorin, Ilorin, Nigeria for the GC/MS analysis are appreciated.

doxa subsp. nilotica) ethno-varieties in Uganda. Ethnobotany Research and Applications 9, 243-256.

Hagerman, A., Harvey-Mueller, I., Makker, H. P., 2000: Quantification of tannins in the foliage-a laboratory manual. FAO/ IAEA, Vienna, Austria.

Hall, J. B., Aebischer, D. P., Tomlison, H. F., Osei-Amaning, E., Hindle, J. R., 1996: Vitellaria paradoxa: a monograph. School of Agricultural and Forest Sciences, University of Wales, Bangor.

Ilorin Atlas, 1982: Geography Department, University of Ilorin Press, Ilorin, Nigeria.

Kalayasiri, P., Jayashke, N., Krisnangkura, K., 1996: Survey of seed oils for use as diesel fuels. Journal of America Oil Chemists' Society 73, 471-474.

Kobomoje, O. S., Mohammed, A. O., Omojasola, P. F., 2013: The production of gibberellic acid from shea nut shell (Vitellaria paradoxa) using Fusarium moniliforme. Asian Journal of Plant Science and Research 3, 23-26.

Kokate A., 1999: Phytochemical methods. phototherapy (2nd ed). Spectrum Books Ltd, Ibadan.

Kraft, J. N., Lynde C.W., 2005: Moisturizers: what are they and practical approach to product selection. Skin Therapy Letter $10,1-8$.

Kumaran, A., Karunakaran, J., 2006: In vitro antioxidant activities of methanol extracts of five Phyllanthus species from India. LWT-Food Science and Technology 40, 344-352.

Lamien, N., Tigabu, M., Guinko, S., Oden, P. C., 2007: Variations in dendrometric and fruiting characters of Vitellaria paradoxa populations and multivariate models for estimation of fruit yield. Agroforestry System 69, 1-11.

Lipp, M., Simoneau, C., Ulberth, F., Anklam, E., Crews, C., Breteron, P., de GreyW., Schwack, W., Wiedmaier, C., 2001: Composition of genuine cocoa butter and cocoa butter equivalents. Journal of Food Composition Analysis 14, 399-408.

Lovett, P. N., Haq, N., 2000: Diversity of shea nut tree (Vitellaria paradoxa C.F. Gaertn) in Ghana. Genetic Resources and Crops Evolution 47, 293-304.

Maranz, S., Weisman, Z., Bisgaard, J., Bianchi, G., 2004: Germplasm resources of Vitellaria paradoxa on variation in fat composition across the species distribution range. Agroforestry System 60, 71-76.

Masters, E. T., Yidana, J. A., Lovett, P. N., 2010: Trade and sustainable forest management. Retrieved November 2016 from http://www.fao.org/docrep/008/y5918e/y5918e11.htm.

Mbaiguinam, M., Mbayhoudel, K., Djekota, C., 2007: Physical and chemical characteristics of fruits, pulps, kernels and butter of shea Butyrospermum parkii (Sapotaceae) from Mandoul, Southern Chad. Asian Journl of Biochemistry 2, 101-110.

Moore, S., 2008: The role of Vitellaria paradoxa in poverty reduction and food security in the Upper East region of Ghana. Earth and Environment 3, 209-245.

Nafan, D., Bup, N. D., Kapseu, C., Kouame, C., Sangare, A., 2007: Phenotypic diversity of shea (Vitellaria paradoxa C.F. Gaertn.) populations across four agro-ecological zones of Cameroon. Journal of Crop Science and Biotechnology 10, 211-218.

National Geographical Information Agency (NGIA), USA, 2016: Department of Defense: Military location information. 
Nielson, S., 2003: Food analysis, laboratory manual. 3th Edition. Kluwer Academic Premium Publishers, London.

Nigerian Metrology Agency (NIMET), 2016: Weather data of Kwara State for 20 years (1995-2015).

Nwosu, J. N., Ezegbe, C. C., Omeire, G. C., Ahaotu, L., Owuamanam, C. I., Udeozor, L. O. 2012: Evaluation of the proximate properties of the seed and physicochemical properties of the oil of Chinese fan palm (Livistona chinensis). International Journal of Basic and Applied Sciences 1, 304312.

Obadoni, B.O., Ochuko, P. O., 2001: Phytochemical studies and comparative efficacy of the crude extract of some homeostatic plants in Edo and Delta states of Nigeria. Global Journal of Pure and Applied Sciences 8, 203-208.

Obasi, N. A., Ukadilonu, J., Eze, E., Akubugwo, E. I., Okorie, U. C., 2012: Proximate composition, extraction, characterization and comparative assessment of coconut (Cocos nucifera) and melon (Colocynthis citrullus) seeds and seed oils. Pakistan Journal of Biological Sciences 15, 11-18.

Olaniyan A.M., Oje, K., 2007: Quality characteristics of shea butter recovered from shea kernel through dry extraction process. Journal of Food Science and Technology 44, 40-44.

Onwuliri, F. C., 2004: Antimicrobial studies of the extracts of Acalypha wilkesiana L. on microorganisms associated with wound and skin infections. West African Journal of Biological Science 15, 1519.

Ozcan, M. M., Iman, C., Arsian, D., 2010: Physico-chemical properties, fatty acid and mineral content of walnuts (Juglans regia L.) types. Agricultural Sciences 1, 62-67.

PubChem, 2014. Elaidic Acid. Retrieved on December 2014 from https://pubchem.ncbi. nlm.nih.gov/compound/Elaidic_acid.

Raimi, M. M., Adegoke, B. M., Afolabi, O., 2014: Nutritional composition of seed and physicochemical properties of seed oil of Vitellaria paradoxa. Scientific Research Journal 2, 35-39.

Rogers, S., Lenick, A., 2009. Shea butter alkoxylates. United States Patent (US 7544824 B2) Retrieved on February 2015 from http://www.freepatentsonline.com/7544824.pdf.

Sanou, H., Lovett, P. N., Bouvet, J. M., 2005: Comparison of quantitative and molecular variation in agroforestry populations of the shea tree (Vitellaria paradoxa C. F. Gaertn) in Mali. Molecular Ecology 14, 2601-2610.
Sofowora, A., 1993: Medicinal plants and traditional medicine in Africa. Spectrum Books Ltd., Ibadan, Nigeria.

Soloviev, P., Daouda Niang, T., Gaye, A., Totte, A., 2004: Variabilité des caractères physico-chimiques des fruits de trois espèces ligneuses de cueillette récoltés au Sénégal: Adansonia digitata, Balanites aegyptiaca and Tamarindus indica. Fruits 59, 109-119.

Soro, D., Kass, N. J., Traore, K., 2011: Effect of the temperature and rainfall on shea tree fruit production. Journal of Agricultural and Biological Sciences 2, 220-226.

Tremblay, R. L., Ackerman, J. D., Pérez, M. E., 2010: Riding across the selection landscape: fitness consequences of annual variation in reproductive characteristics. Philosophical Transactions of the Royal Society B: Biological Sciences 365, 491-498.

Ugbogu A. E., Akubugwo, E. I., Uhegbu, F. O., Chinyere, G. C., Ugbogu, O. C., Oduse, K. A., 2013: Nutritional and chemical composition of Jatropha curcas (L.) seed oil from Nigeria. International Journal of Biosciences 3, 125-134.

Velasco, M. V. R., Sarruff, F. D., Salgado-SantosI. M. N., Haroutiounian-Filho C. A., Kaneko, T. M., Baby, A. R., 2008: Broad spectrum bioactive sunscreen. International Journal of Pharmaceutics 363, 50-57.

Walter, S., Cole, D., Kathe, W., Lovett, P., Paz Soldan, M., 2003: Impact of certification on the sustainable use of NWFP: Lessons learnt from three case studies. Proceedings of the International Conference on Rural Livelihoods, Forests and Biodiversity, Bonn, Germany.

Warra, A. A., 2011: Cosmetic potential of African shea nut (Vitellaria paradoxa) butter. Current Research in Chemistry 3, 80-86.

Warra, A. A., 2015: GC-MS Analysis of various extracts of shea nut fat. American Journal of Biological Chemistry 3, 67-73.

Warra, A. A., Komo, J. I., 2014: Fat quality and cold saponification of shea nut (Vitellaria paradoxa) fat extract. Journal of Scientific Research and Reports 13, 660-607.

Warra, A. A., Wawata, I. G., Hassan, L. G., Gunu, S. Y., Aujara, K. M., 2011: Extraction and physicochemical analysis of some selected Northern Nigerian industrial oils. Archives of Applied Science Research 3, 536-541.

Yadav, R. N. S., Agarwal, M., 2011: Phytochemical analysis of some medicinal plants. Journal of Phytology 3, 10-14. 